\title{
Sığ Akım Denklemlerinin Hidrolikte Kullanılması Üzerine Değerlendirmeler
}

\author{
Behiye Nilay IȘCEN ${ }^{1}$ \\ Nuray ÖKTEM ${ }^{2}$ \\ Burak YILMAZ ${ }^{3}$ \\ İsmail AYDIN ${ }^{4}$
}

\section{ÖZ}

Sığ akım denklemlerinin geniş alanlara yayılan taşkınları hesaplamada başarılı olduğu bilinmekte ve bu denklemler taşkın analizleri için yaygın olarak kullanılmaktadır. Kentsel alanlardaki yapılar arasında ilerleyen taşkınlar ve köprü gibi hidrolik yapılar etrafındaki akımlar sı̆̆ akım sınırlamalarını tam olarak sağlamamakta ve daha çok 3-Boyutlu (3B) akım özelliği taşımaktadır. Ancak, hızlı sayısal çözüm kolaylığı bakımından sığ-akım denklemleri bu tür 3B akımlar için de kullanılabilmekte ve yararlı çıktılar elde edilebilmektedir.

$\mathrm{Bu}$ çalışmada, sı̆̆ akım denklemleri, 3B özellikleri öne çıkan akımlara uygulanarak sonuçları değerlendirilmiştir. Su derinliği ve yatay düzlemde hız dağılımımın yeterli ayrıntıda hesaplanabildiği, sel rejiminde su yüzünde oluşan şok dalgalarının ayrıntılı olarak tanımlanabildiği gözlenmiştir. Ancak, birden fazla 3B engel etrafından geçen akımlarda su derinliği hesaplamadaki hataların eklenerek arttığı belirlenmiştir. Sınır tabaka özelliklerinin öne çıktığı üniform akım durumunda uygun bir türbülans modeli kullanılması halinde, hız ve yatak kesme gerilmeleri dağılımlarının da başarıyla hesaplanabildiği gösterilmiştir.

Anahtar Kelimeler: Sel, taşkın, sığ akım denklemleri, şok yakalayıcı çözümler, Riemann çözücüler.

\section{ABSTRACT}

\section{On the Use of Shallow Water Equations in Hydraulics}

Shallow water equations are widely used in inundation analysis and they are known to be successful in computation of floods over wide terrains. Flood propagation in between buildings in urban areas and flows around hydraulic structures such as bridges may not satisfy the assumptions of shallow flow and may display markedly more 3-Dimensional

Not: Bu yazı

- Yayın Kurulu'na 31.07.2015 günü ulaşmıştır.

- 31 Mart 2017 gününe kadar tartışmaya açıktır.

1 Orta Doğu Teknik Üniversitesi, İnşaat Mühendisliği Bölümü, Ankara - bnilayiscen@gmail.com 2 Çanakkale Onsekiz Mart Üniversitesi, Matematik Bölümü, Çanakkale - nbozkaya@gmail.com 3 Orta Doğu Teknik Üniversitesi, İnşaat Mühendisliği Bölümü, Ankara

4 Orta Doğu Teknik Üniversitesi, İnşaat Mühendisliği Bölümü, Ankara - ismaydin@metu.edu.tr 
Siğ Akım Denklemlerinin Hidrolikte Kullanılması Üzerine Değerlendirmeler

(3D) flow characteristics. However, for the convenience of fast numerical solutions, the shallow-current equations can also be used for such 3D flows and useful output may be obtained.

In this study, shallow water equations are applied to flows with prominent 3D characteristics and results are evaluated. Water depths and velocity field in horizontal plane were calculated satisfactorily, surface waves in supercritical flow involving shocks were described in detail. However, it has been determined that the flow around several 3D obstacles increases by adding faults that calculate water depth. In case of uniform flows with boundary layer characteristics, velocity and bed shear stresses were predicted successfully using a suitable turbulence model.

Keywords: Flood, inundation, shallow water equations, shock capturing solutions, Riemann solvers.

\section{GíRiş}

Serbest yüzeyli akımlar içeren hidrolik mühendisliği uygulamalarında akım koşullarının detaylı bir analizini yapabilmek için su derinliğinin hesaplanması bir ilk adımdır. Bu amaçla 1B integral denklemlerin sayısal çözümü yaygın bir uygulama olup 20. yüzyılın ikinci yarısından itibaren nehir mühendisliği hesaplamalarında kullanılmaktadır. Bilgisayarların gelişmesi ile daha da kolaylaşan tek boyutlu çözümler özellikle baraj yıkılması gibi taşkın dalgalarının ilerlemesini hesaplamada kullanılmıştır.

Doğal ortamlardaki akımlar daima 3B olduğu halde, mühendislik uygulamalarında pratik ve hızlı bir çözüm elde edebilmek amacıyla, $2 \mathrm{~B}$ veya $1 \mathrm{~B}$ basitleştirilmiş matematik modellerden yararlanılabilir. Günümüzde, sadece sınırlı büyüklükteki alanlarda, dolu savak, enerji kırıcı havuz ve köprü gibi önemli hidrolik yapıların etrafında kapsamlı 3B sayısal çözümler yapılabilmektedir. Onlarca kilometre uzayıp giden nehir yatakları ya da taşkın alanları için 3B çözümler ekonomik olmadığı gibi, gerekli de değildir. Taşkın analizi yapılacak alanlarda akımın zamana karşı ilerleyişini doğru hesaplayabilmek için, zamanda hassas çözümler yapılması gereklidir. Ancak, akım parametrelerinin düşey yöndeki değiş̧imi taşkın analizi için önemli olmadığından denklemlerin düşey yönde (derinlik üzerinde) integrali alınarak, derinlik ortalamalı değerler için çözülmesi yeterli olmaktadır. Bu durumda süreklilik denklemi derinlik için, yatay yönlerdeki iki momentum denklemi de yatay hız bileşenleri için çözülmektedir. Derinlik integralli akım denklemleri 'Sı̆̆ Akım Denklemleri' (SAD) olarak adlandırılmakta olup taşkın akımları dışında göllerde, kıyı alanlarında dalga ilerlemesinde, okyanuslarda akıntı ve çevrinti hesabında ve atmosfer katmanlarındaki tabaka akımlarının hesaplanmasında kullanılmaktadır. Denklemlerin geçerliliği için temel koşul, akım alanında yatay boyutun düşey boyuttan yeterince büyük olmasidir.

Herhangi bir serbest yüzeyli akım için SAD kullanıldığında sayısal çözüm bakımından önemli avantajlar kazanılmaktadır. Süreklilik denklemi doğrudan su derinliği için çözüldüğünden, 3B sayısal çözümdeki su yüzeyinin konumunun belirlenmesi problemi ortadan kalkmaktadır. Ayrıca, derinlik integrali sırasında düşey yöndeki ivme ihmal edildiğinden, aynı yönde hidrostatik basınç dağılımı kabulü de yapılmış olmaktadır. Böylece, SAD çözümünde basınç için bir denklem çözümüne ihtiyaç kalmamaktadır. Bu durum matematik ve sayısal yönden önemli sadeleşme sağlamakta ise de denklemlerin 
farklı problemlerde kullanımına fiziki anlamda önemli kısıtlamalar getirmektedir. $\mathrm{Bu}$ çalışmada bu konunun tartışılması amaçlanmıştır.

\section{SIĞ AKIM DENKLEMLERİ (SAD)}

Navier-Stokes denklemlerinin derinlik yönünde integrali alınarak [1] elde edilen SAD takımı, süreklilik denklemi ve yatay yöndeki iki momentum denkleminden oluşur. Denklem takımının ve sayısal çözümün toplu bir sunumunu yapabilmek için vektör notasyonu kullanılacaktır.

$\frac{\partial \boldsymbol{U}}{\partial t}+\nabla \cdot \boldsymbol{F}^{\boldsymbol{c}}=\boldsymbol{S}+\nabla \cdot \boldsymbol{F}^{d}$

Burada, $t$ zamanı, $\boldsymbol{U}$ bağımlı değişkenleri, $\boldsymbol{F}^{\boldsymbol{c}}=\left(E^{c}, G^{c}\right)$ konvektif akıyı, $\boldsymbol{F}^{\boldsymbol{d}}=\left(E^{d}, G^{d}\right)$ difüzif akıyı, $\nabla$ del operatörü ve $S$ ilgili denklemin kaynak terimlerini gösteren vektördür. Vektörlerin bileşenlerinin açık tanımları Denklem (2)'de matrisler halinde verilmiştir.

$$
\begin{aligned}
& \boldsymbol{U}=\left[\begin{array}{c}
h \\
h u \\
h v
\end{array}\right], \quad E^{c}=\left[\begin{array}{c}
h u \\
h u^{2}+\frac{1}{2} g h^{2} \\
h u v
\end{array}\right], \quad G^{c}=\left[\begin{array}{c}
h v \\
h u v \\
h v^{2}+\frac{1}{2} g h^{2}
\end{array}\right], \quad E^{d}=\left[\begin{array}{c}
0 \\
\frac{h}{\rho} \tau_{x x} \\
\frac{h}{\rho} \tau_{x y}
\end{array}\right], \\
& G^{d}=\left[\begin{array}{c}
0 \\
\frac{h}{\rho} \tau_{y x} \\
\frac{h}{\rho} \tau_{y y}
\end{array}\right], \quad S=\left[\begin{array}{c}
0 \\
g h\left(S_{0, x}-S_{f, x}\right) \\
g h\left(S_{0, y}-S_{f, y}\right)
\end{array}\right]
\end{aligned}
$$

Burada $h$ su derinliği, $u$ ve $v$ derinlik ortalamalı hızlar, $h u x$-yönündeki birim debi, $h v y$ yönündeki birim debi, $g$ yerçekimi ivmesi, $\rho$ suyun yoğunluğu, $\tau$ viskoz ve türbülans gerilmelerin toplamı, $S_{0}$ taban eğimi, $S_{f}$ sürtünme eğimidir. Denklem (2)'de sayısal çözüm tekniği bakımından uygun olduğu için basınç terimleri de konvektif terimler içinde verilmiş̧tir. Sürtünme eğiminin hesabında klasik Manning pürüzlülük parametresi $n$ 'den yararlanılır.

$$
S_{f, x}=\frac{n^{2} u \sqrt{u^{2}+v^{2}}}{h^{4 / 3}}, \quad S_{f, y}=\frac{n^{2} v \sqrt{u^{2}+v^{2}}}{h^{4 / 3}}
$$

Birçok SAD çözümünde viskoz terimler ve türbülans hiç dikkate alınmamaktadır. Özellikle, baraj yıkılması ve taşkın ilerlemesi problemleri için bu kabul yaygındır. Ancak, yatay düzlemde sirkülasyon ve vorteks oluşumunun önemli olduğu durumlarda viskoz etkiler ve türbülans gerilmeler çözüme dahil edilmektedir. Ayrıca, katı yapıların yakın 
Siğ Akım Denklemlerinin Hidrolikte Kullanılması Üzerine Değerlendirmeler

çevresindeki akımların hesabında, doğru (kaymaz) sınır koşullarını uygulayabilmek ve gerçekçi hız dağılımları elde edebilmek için viskoz terimler matematiksel olarak da gereklidir. Derinlik integralli bir matematik model için ayrıntılı bir türbülans modeline gerek duyulmadan, klasik türbülans viskozitesi yaklaşımından yararlanarak toplam gerilmeler aşağıdaki gibi yazılabilir.

$\tau_{i, j}=\left(v+v_{\mathrm{t}}\right)\left(\frac{\partial u_{i}}{\partial x_{j}}+\frac{\partial u_{j}}{\partial x_{i}}\right)$

Burada, $v$ kinematik moleküler viskozite ve $v_{\mathrm{t}}$ kinematik türbülans viskozitesidir.

Hesaplamalı Akışkanlar Dinamiği (HAD) çözümlemelerinde başarı, önemli ölçüde problemin sınır koşullarının doğru uygulanmasına bağlıdır. Sınır koşulları sayısal yakınsamayı etkilediği gibi, çözümün fiziksel geçerliliğini de belirler. SAD çözümlerinde karşılaşılabilecek sınır tipleri; akım girişi, akım çıkışı, duvar, simetri ve periyodik olabilir. Her sınır tipinde tanımlanması gereken sınır koşulları ve değişken sayısı kullanılan matematik modelin yanı sıra akımın kritik-altı veya kritik-üstü olmasıyla da değişmektedir.

\section{SAYISAL ÇÖZÜM}

SAD lineer olmayan, hiperbolik karakterli kısmi diferansiyel denklemlerdir. En önemli özelliği, su yüzünde oluşabilecek şok dalgalarından dolayı çözümünde süreksizliklerin bulunmasıdır. Çözümdeki süreksizliğin en anlaşılır örneği 'ani baraj yıkılması' olarak adlandırılan idealize edilmiş bir düşey duvar arkasındaki hidrostatik suyun, duvarın ani kaldırılması ile dayanaksız kalması halidir. O noktada hesaplanan su yüzü eğimi sonsuzdur. Başlangıçta düşey duvara paralel olan su, hızla deforme olarak tamamen yatay bir konuma gelinceye kadar akım hali devam edecektir. Membada hidrostatik durumla başlayan akım probleminin, mansapta farklı bir yatak içinde tekrar hidrostatik duruma gelinceye kadar geçen sürecin hesaplanması söz konusudur. Dolayısıyla, sayısal çözüm yönteminin bağımlı değiş̧kenlerdeki süreksizliği düzlemeden olduğu gibi yakalayabilmesi ve değişkenlerin zamanda değişimini doğru olarak hesaplayabilecek yetenekte olması gerekir. Standart sonlu farklar yönteminde türevler noktasal olarak sonlu farklar ile ifade edilir. Bu tür yaklaşımlar özellikle süreksizlikler civarında beklendiği gibi çalışmamaktadır. Sonlu hacim yöntemleri süreksizlikleri çözebilmek bakımından daha uygundur. Sonlu hacim yöntemlerinde akımın gerçekleştiği uzay, ağ hücresi olarak adlandırılan göreceli küçük sonlu hacimlere bölünmektedir. Bu metot sayısal çözümde her hücredeki ortalama değerin hesaplanmasını sağlamaktadır. Her zaman adımında, önce hücre yüzeylerindeki akılar bulunarak ilgili değişkenin hücre içindeki ortalama değeri hesaplanır. Sayısal çözümün başarısı yüzeylerdeki akıların, değişkenlerin süreksizliği durumunda da doğru olarak bulunmasına bağlı olup, bazen çok problemli olabilmektedir.

Hiperbolik kısmi diferansiyel denklemler yayılma problemlerini tanımlar. Doğadaki birçok akım basitçe dalga karakteri olarak tanımlanabilecek hiperbolik özellik taşımaktadır. Bu tür bir akımda, bir noktadaki değişkenin önceki değeri başka bir noktadaki anlık değeri etkileyerek akım koşullarını değiştirebilir. Diğer bir ifade ile bir noktadaki çözüm bilgisi akımla birlikte ilerlemektedir. Hücre yüzeylerindeki akıların hesaplanmasında farklı hesap 
şemaları kullanılabilmekte ve bu da sayısal çözümü önemli ölçüde etkilemektedir. Yaygın olarak kullanılan 'rüzgar yönlü şemalar' yüzeylerdeki akıları bulurken akım yönünü dikkate aldığından daha doğru sayısal akı hesaplamasına olanak verirler.

Hücre yüzeylerindeki akılar hesaplanırken her değişken için süreksizlik olabileceği düşünülerek tek yönlü bir Riemann problemi çözülmektedir. Riemann problemi tanımı, bir hesap hücresinin herhangi bir yüzeyinde bağımlı bir değişkenin, yüzeye sağdan veya soldan yaklaşılması durumlarında değerinin birbirinden farklı olabileceği kabulüne dayanmaktadır [2]. Bu durumda hücre yüzeyindeki akı, olası tüm dalga oluşumları; şok (shock), seyreltme (rarefaction), temas süreksizliği (contact discontinuity) ve bütün değişsenlerin etkileşimleri de dikkate alınarak bulunmalıdır. Bu işlem karmaşı bir koşullar ve karşılaştırmalar dizisi içermekte olup literatürde 'Riemann çözücüler' olarak bilinmektedir. Riemann problemi tam olarak çözülebilmekle beraber, daha az hesap süresi gerektiren 'yaklaşık Riemann çözücüler' de yaygın olarak kullanılmaktadır. Riemann problemi tanım olarak tek boyutlu olsa da, çok boyutlu problemlerin çözümünde de (her yönde ardışı uygulama ile) yaygın olarak kullanılmaktadır.

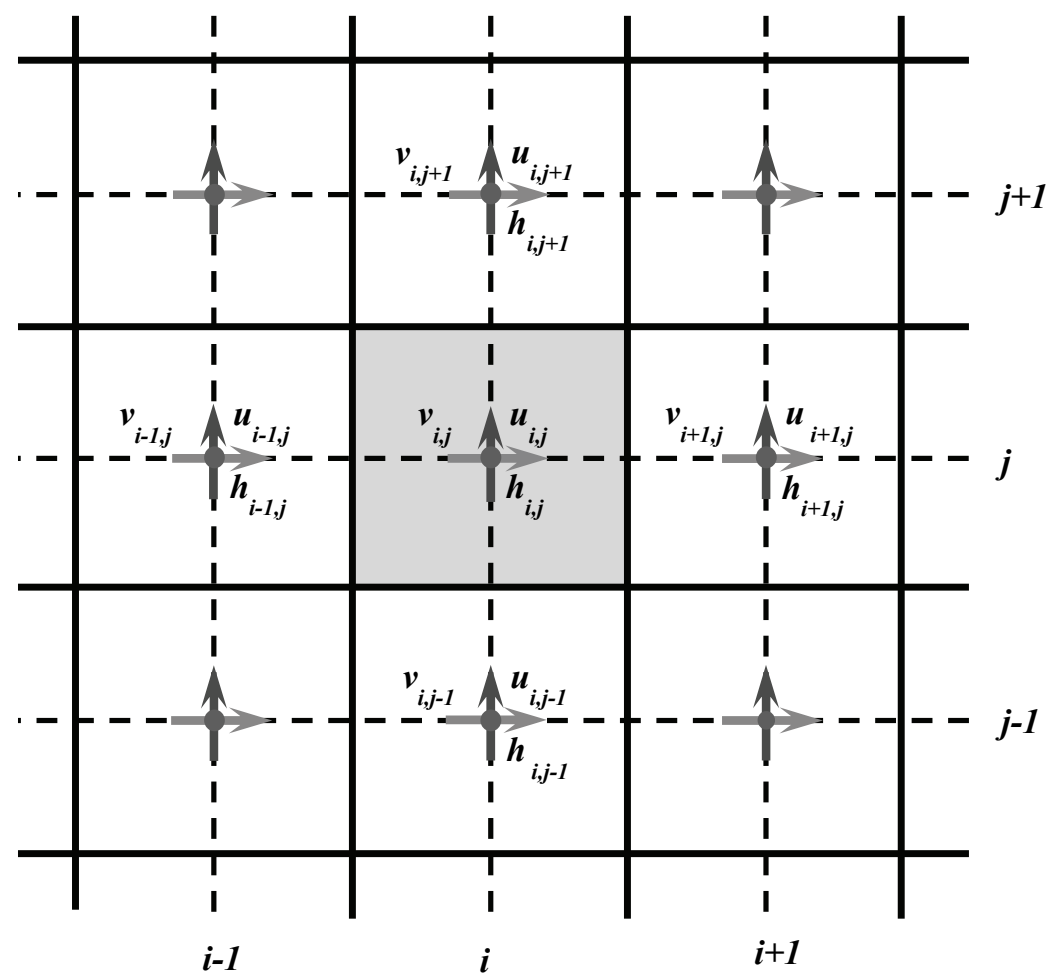

Şekil 1. Hesap ăğ ve bă̆ımlı değişkenlerin tanımlanması [3] 
Siğ Akım Denklemlerinin Hidrolikte Kullanılması Üzerine Değerlendirmeler

Rüzgar yönlü şema ve Riemann çözücülerden yararlanarak önceki sayısal yöntemlerin eksikliklerini gideren Godunov metodu HAD uygulamalarına yeni bir boyut getirmiştir. Temel olarak birinci derece rüzgar yönlü şema ile lineer olmayan korunum kanunlarının çözümünde süreksizlikler civarında en doğru çözümü elde etmeyi amaçlamaktadır. Tam ya da yaklaşık Riemann çözücüler Godunov metodunun esas elemanlarıdır. Metot her zaman adımında ve her hücreler arası yüzeyde Riemann probleminin çözümüne dayanmaktadır. Siralı (structured) dikdörtgen bir hesap ağında (Şekil 1) Denklem (1)'in sonlu hacim yöntemi ile ayrıklaştırılmış hali aşağıda verilmiştir.

$$
\begin{aligned}
\boldsymbol{U}_{i, j}^{n+1} & =\boldsymbol{U}_{i, j}^{n}-\frac{\Delta t}{\Delta x}\left(E_{i+\frac{1}{2}, j}^{c}{ }^{n}-E_{i-\frac{1}{2}, j}^{c}{ }^{n}\right)-\frac{\Delta t}{\Delta y}\left(G_{i, j+\frac{1}{2}}^{c}{ }^{n}-G_{i, j-\frac{1}{2}}^{c}{ }^{n}\right) \\
& +\frac{\Delta t}{\Delta x}\left(E_{i+\frac{1}{2}, j}^{d}{ }^{n}-E_{i-\frac{1}{2}, j}^{d}{ }^{n}\right)+\frac{\Delta t}{\Delta y}\left(G_{i, j+\frac{1}{2}}^{d}{ }^{n}-G_{i, j-\frac{1}{2}}^{d}{ }^{n}\right)+\Delta t \boldsymbol{S}_{i, j}{ }^{n}
\end{aligned}
$$

Burada $\boldsymbol{U}_{i, j}^{n}$ hesap hücre merkezindeki bağımlı değişken, $i, j \quad x$-ve $y$-yönündeki hücre indisi, $n$ zamandaki adım üst indisi, $\Delta t$ zamanda adım, $\Delta x$ ve $\Delta y$ hücre boyutları, $\boldsymbol{F}^{\boldsymbol{c}}$ ve $\boldsymbol{F}^{\boldsymbol{d}}$ hücre yüzeylerinde toplam (konvektif + difüsif) ak1 ve $S$ hücre merkezindeki kaynak terimidir. Konvektif akılar Riemann problemi çözümünden elde edildiğinde, Denklem (5) ile verilen sonlu hacim formülü uzayda ikinci dereceden doğru ve şok yakalayıcı (shock capturing) özelliğine sahiptir. Çözümün zamanda da ikinci dereceden doğru olması için iki adımlı, öngören-düzelten yaklaşımından yararlanılır [4]. Önce, zamanda yarım adımla öngörülen değerler bulunur.

$$
\begin{aligned}
\boldsymbol{U}_{i, j}^{P} & =\boldsymbol{U}_{i, j}^{n}-\frac{\Delta t}{2 \Delta x}\left(E^{c}{ }_{i+\frac{1}{2}, j}^{n}-E^{c}{ }_{i-\frac{1}{2}, j}{ }^{n}\right)-\frac{\Delta t}{2 \Delta y}\left(G^{c}{ }_{i, j+\frac{1}{2}}^{n}-G^{c}{ }_{i, j-\frac{1}{2}}^{n}\right) \\
& +\frac{\Delta t}{2 \Delta x}\left(E_{i+\frac{1}{2}, j}^{d}{ }^{n}-E_{i-\frac{1}{2}, j}^{d}{ }^{n}\right)+\frac{\Delta t}{2 \Delta y}\left(G_{i, j+\frac{1}{2}}^{d}{ }^{n}-G_{i, j-\frac{1}{2}}^{d}{ }^{n}\right)+\frac{\Delta t}{2} \boldsymbol{S}_{i, j}{ }^{n}
\end{aligned}
$$

Denklem (6)'da üst indis ' $P$ ' yarım zaman adımındaki öngörülen değerleri gösterir. İkinci aşamada tam zaman adımı ile $n+1$ seviyesinde düzeltilmiş değerler hesaplanır.

$$
\begin{aligned}
\boldsymbol{U}_{i, j}^{n+1} & =\boldsymbol{U}_{i, j}^{n}-\frac{\Delta t}{\Delta x}\left({E^{c}}^{c}{ }_{i+\frac{1}{2}, j}^{P}-E^{c}{ }_{i-\frac{1}{2}, j}{ }^{P}\right)-\frac{\Delta t}{\Delta y}\left(G^{c}{ }_{i, j+\frac{1}{2}}^{P}-G^{c}{ }_{i, j-\frac{1}{2}}^{P}\right) \\
& +\frac{\Delta t}{\Delta x}\left(E_{i+\frac{1}{2}, j}^{d}{ }^{n}-E_{i-\frac{1}{2}, j}^{d}{ }^{n}\right)+\frac{\Delta t}{\Delta y}\left(G_{i, j+\frac{1}{2}}^{d}{ }^{n}-G_{i, j-\frac{1}{2}}^{d}{ }^{n}\right)+\Delta t \boldsymbol{S}_{i, j}^{P}
\end{aligned}
$$

Hesap hücre yüzeylerindeki konvektif akıların hesabında Riemann problemini yaklaşı çözen Roe metodu kullanılmıştır. Bu metodun tanımı ve başarımı hakkında çok sayıda çalışma yapılmış ve yayımlanmıştır ([4], [5]), bu nedenle burada tekrarlanmayacaktır. Sayısal çözümün diğer önemli öğesi ise hesaplanan akıları sınırlamada kullanılan eğim- ya da akı-sınırlayıcılarıdır. Herhangi bir noktada, bir değişkenin eğimi süreksizlik nedeniyle 
sonsuz büyüklükte olabilir. Böyle bir durumda hesaplamanın sürdürülebilmesi için hesaplanan eğimde (veya akıda) sınırlamalara gidilir. Eğim sınırlama işlemini yapan çok sayıda ampirik fonksiyon ilgili literatürde mevcuttur. Bu çalışma boyunca Superbee, Van Leer, Van Albada ve Minmod sınırlayıcıları kullanılmıştır [6].

Denklemler (6) ve (7) ile tanımlanan ardışık hesaplamaların istikrarlı bir şekilde gerçek çözüme ulaşabilmesi için, zaman adımında sınırlama gereklidir. Bu çalışmada kullanılan zaman adımı bir CFL sayısı belirleyerek aşağıdaki formülden hesaplanmıştır.

$\Delta t=\operatorname{CFL} \min \left\{\frac{\Delta x, \Delta y}{\left(c+\sqrt{u^{2}+v^{2}}\right)_{i, j}}\right\}$

Burada $c$ dalga hızı $(=\sqrt{g h})$ olup, tüm çözümlerde CFL sayısı 0.5 olarak sabitlenmiştir. Yukarıda tanımlanan sayısal model, FORTRAN bilgisayar dilinde kodlanarak çalıştırılmış ve öncelikle 1B baraj yıkılması test problemleri için koşturulmuştur. Sonuçlar literatürde mevcut analitik çözümlerle karşılaştırılmış, tanımlanan algoritmanın başarımı test edilmiş ve daha önce diğer araştırmacılar tarafından rapor edilen sonuçların aynı doğrulukta tekrarlandığı görülmüştür. Burada kullanılan çözüm yönteminin başarımı ile ilgili olarak, 1B testler ilgili literatürde ([7], [8], [9]) farklı araştırmacılar tarafından yayımlandığı için burada tekrarlanmayacaktır. Daha sonra bu çalışmanın ana fikri kapsamında 3 ayrı akım durumu dikkate alınmış ve sayısal çözümler ilerleyen bölümlerde ayrıntılı bir şekilde değerlendirilmiştir.

\section{UYGULAMALAR}

\subsection{Prizmatik Kanalda Kübik Engel Etrafında Akım}

Açık kanal akımlarında geometrik geçişlerde yaşanan akım olaylarının doğru canlandırılması, sayısal çözüm yönteminin başarısını göstermek bakımından önemlidir. Kritik-üstü akımlarda yüzeyde oluşan şok dalgalarının etkileşimi, kanal içindeki bir engel nedeniyle daralan kesitten geçen akımın uğradığ olaylarının gerçeğe uygun olarak hesaplanabilmesi, sağlanması gereken koşullardır. Bu tür geçiş akım ayrıntılarını inceleyebilmek için SAD önce literatürdeki birçok uygulama gibi viskoz ve türbülans terimleri olmadan çözülmüştür. Prizmatik bir kanal içinde bir adet kübik engel (Şekil 2) yerleştirilmiş ve akımın bu engel etrafından geçişi incelenmiştir. Sayısal çözüm alanı için kullanılan denklemlere uygun sınır şartlarını tanımlamak amacıyla, duvar sınırlarında viskoz olmayan kayma sınır koşulları uygulanmıştır. Akım yönünde blok etrafında simetrik akım beklendiği için orta eksende simetri koşulu tanımlanarak hesap alanının yarısı için çözüm yapılmıştır. Kanal ve blok duvarlarında, katı yüzeye dik hız bileşenleri sıfır olarak tanımlanırken, yüzeye paralel hızların sıfırdan farklı olmasına izin verilmiştir. Simetri ekseninde ise kütle geçişine izin vermemek için eksene dik hız sıfır olarak tanımlanmıştır. Akım girişi ve akım çıkışında sınır koşullarının tanımlanması akımın rejimi ile ilgilidir [10]. Kritik-altı akımda çıkışta derinlik sabitlenirken girişte her iki yöndeki birim debi sabitlenmiştir. Kritik-üstü akımda ise girişte derinlik ve her iki yöndeki 
Sı ̆̆ Akım Denklemlerinin Hidrolikte Kullanılması Üzerine Değerlendirmeler

birim debiler sabitlenirken, çıkışta tüm bağımlı değişkenlerin birinci türevleri sıfırlanmıştır. Hızlar ise her zaman birim debi ve derinlikten hesaplanan değerlerdir.

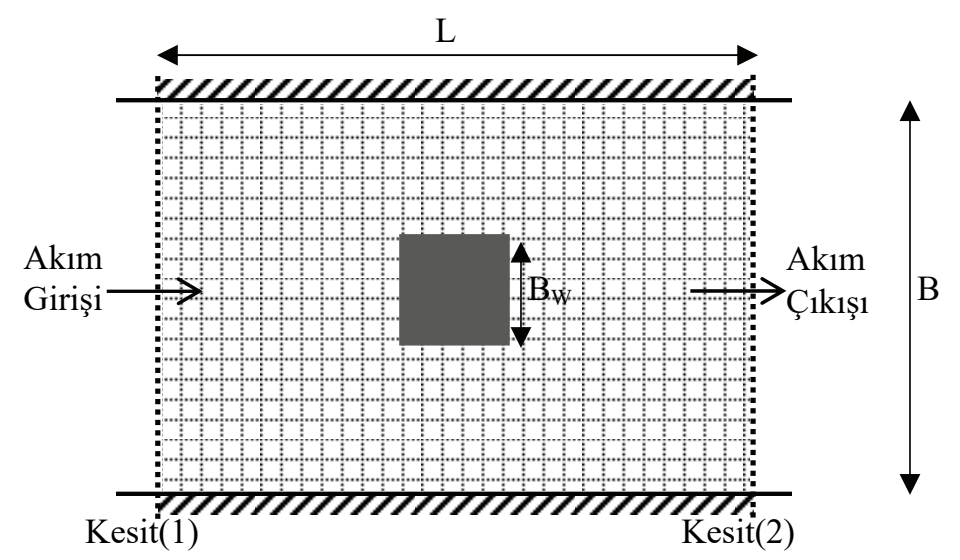

Şekil 2. Kübik engel etrafinda akım için hesaplama alanı tanımlanması [3]

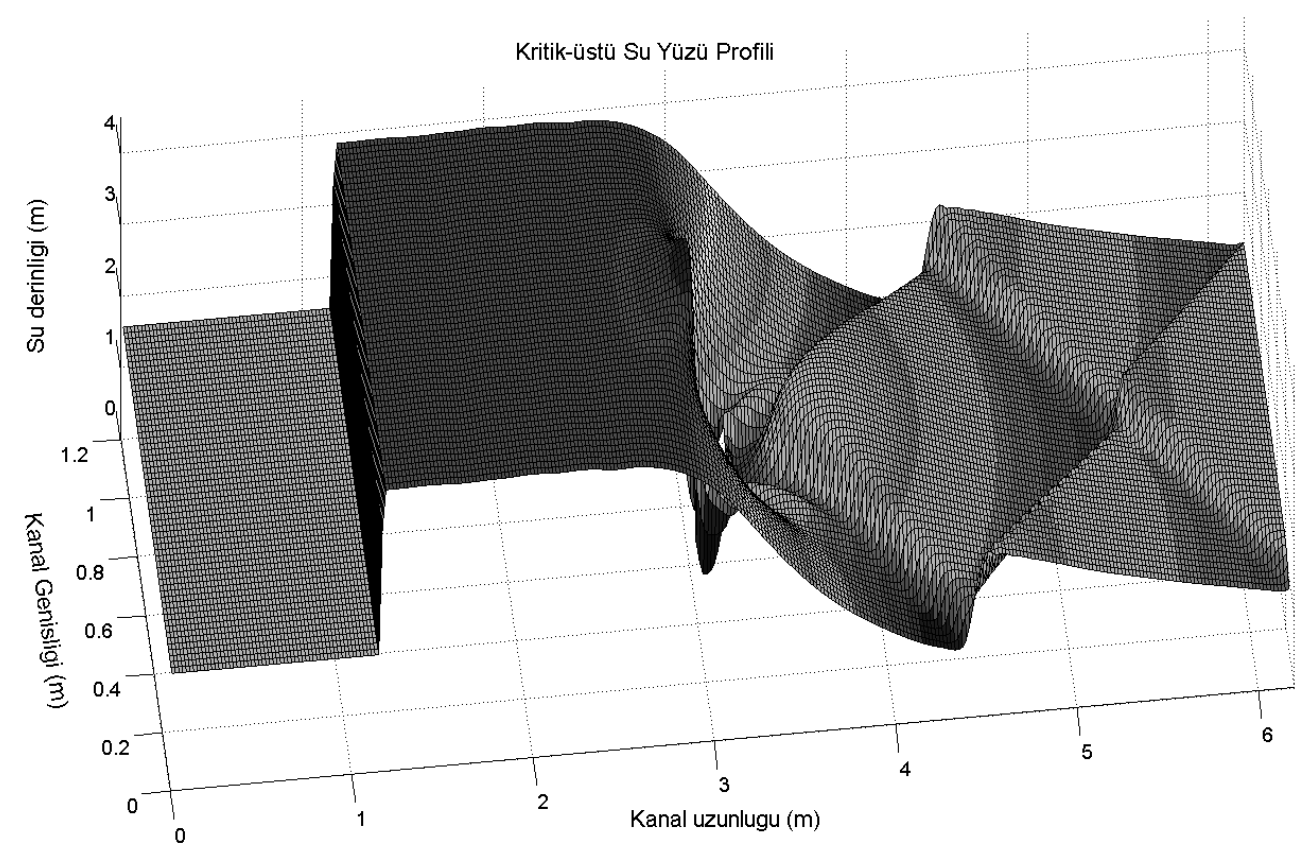

Şekil 3. Kübik blok etrafinda kritik-üstü akımda su yüzü profili [3] 


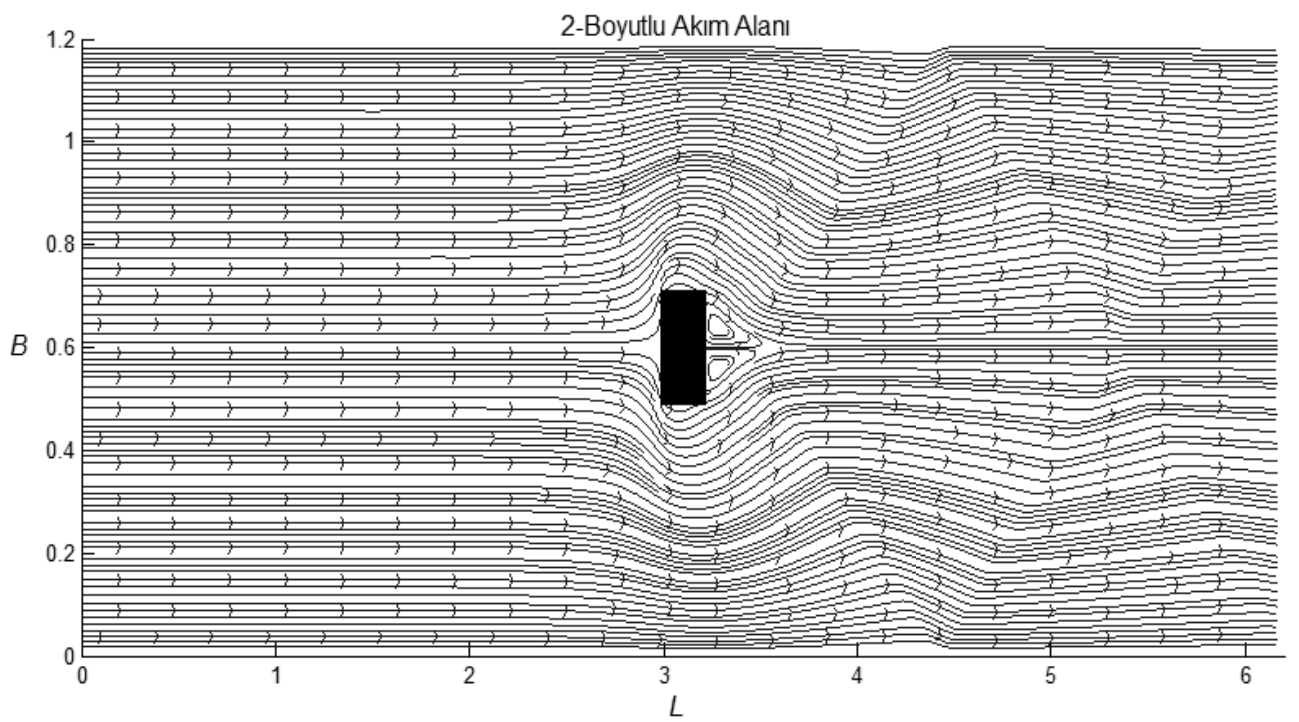

Şekil 4. Kübik blok etrafinda kritik-üstü akımda yatay düzlemde akım çizgileri [3]

Sayısal çözüm ağı kare elemanlardan oluşur ve ağ büyüklüğü sabittir. Çözümün ağ büyüklüğünden bağımsız olduğunu görmek amacıyla üç ayrı büyüklükte hesap hücresinden oluşan ağlar kullanılmış, aynı sonuçların bulunduğu görülmüş ve orta büyüklüğün sonuçları sunulmuştur. $\mathrm{Bu}$ bölümde sunulan sonuçlar $60 \times 310$ hesap hücresinden oluşmaktadır. Kritik-üstü akım için su yüzü profili Şekil 3 'te sunulmuştur. Kübik blok girişten $x=3 \mathrm{~m}$ de yerleştirilmiş olup blok etrafında su yüzündeki sert dalgalanmaları göstermek amacıyla bu şekil içindeki yeri boş bırakılmıştır. Öncelikle, seçilen akım koşullarında blok etrafında akım, enerji yetmezliği nedeniyle boğulmakta (choking) ve enerjiyi yükseltebilmek için de kritik-altı rejime geçmektedir. Rejim değişikliği sonucu blok yukarısında hidrolik sıçrama oluşmaktadır.

Sayısal çözümün başlangıcında tüm hesap alanında kritik-üstü akımın normal derinliği başlangıç değeri olarak verilmiştir. Boğulma ile birlikte, bloğun hemen ön yüzünde hidrolik sıçrama başlamakta ve dengesini bulana kadar yukarı yönde hareket etmektedir. Çalışılan akım zamandan bağımsız olmakla birlikte, çözüm yöntemi bir geçiş (transient) akımı oluşumuna izin vermektedir. Şekil 3 'te sunulan su yüzü profili denge durumu öncesi bloğa yakın bir noktada hidrolik sıçrama göstermekte olup, yeterince uzun bir hesap alanı kullanıldığında hidrolik sıçrama bloktan memba yönünde uzak bir noktaya kayarak sonunda stabilize olmaktadır. Kullanılan sayısal yöntem hidrolik sıçramayı neredeyse düşey, köşeli bir şok dalgası olarak göstermekte ve akım alanı içindeki hareketini herhangi bir sayısal sorun yaratmadan hesaplayabilmektedir. Ayrıca, bloktan sonra oluşan ve duvarlardan yansımalarla birbiri üstüne bindiren baklava dilimi görünümündeki durağan şok dalgaları da, özellikleri gereği tüm çözüm işlemi boyunca yerlerini korumaktadır. $\mathrm{Bu}$ sonuçlar sayısal yöntemin hareketli, hareketsiz her türlü şok dalgasını, hidrolik sıçrama ve boğulma gibi akım geçişlerini hesaplayabildiğini göstermektedir. Özellikle hidrolik 
Siğ Akım Denklemlerinin Hidrolikte Kullanılması Üzerine Değerlendirmeler

sıçramanın son derece dik olarak hesaplanabilmesi, sayısal yöntemin değişkenlerdeki süreksizliği dağıtmadan, olduğu gibi ortaya çıkarabildiğinin kanıtı olarak görülmektedir.

Aynı akım durumu için akım çizgileri Şekil 4'te gösterilmiştir. Çizgilerin netleştirilmesi için şekil orantısız verilmiştir. Kanal ortasındaki kübik engel kare olarak düşünülmelidir. Blok mansabındaki döngüler ve durağan şok dalgalarının duvarlardan yansıyarak baklava dilimi görünümündeki etkileşimi de açık olarak görülmektedir.

Benzer bir sayısal çözüm kritik-altı akım için gerçekleştirilmiş ve elde edilen su yüzü profili Şekil 5'te sunulmuştur. Akım kritik-altı olduğu için blok yukarısında su derinliği artarak bloğun daralttığı kesitten geçmek için gerekli enerjiyi sağlamaktadır. Bu kez herhangi bir şok dalgası oluşmamakta ve akım membada biriktirdiği enerji ile blok etrafından hızlanarak geçebilmektedir.

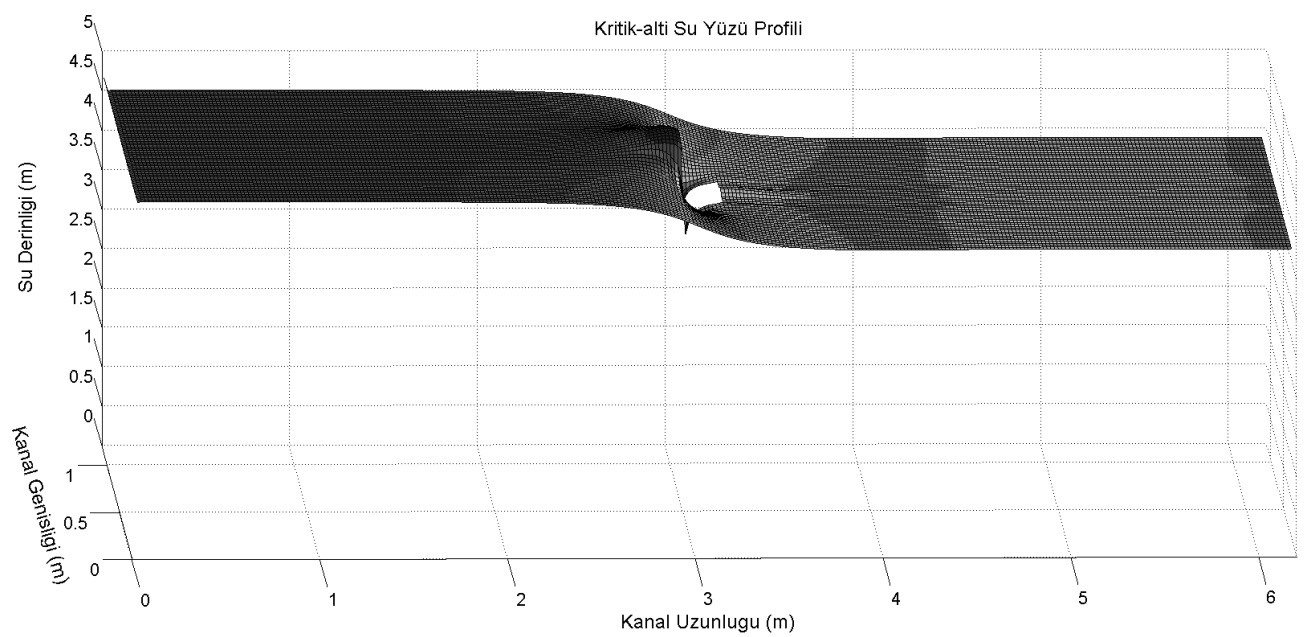

Şekil 5. Kübik blok etrafinda kritik-altı akımda su yüzü profili [3]

\subsection{Prizmatik Kanalda Yerleștirilen Şaşırtmalı Mahmuzlar Arasında Akım}

Bu çalışmada kullanılan ikinci akım konfigürasyonu, birden fazla engel arasından geçen bir kanal akımıdır. Bu bölüm, fiziki bir modelden elde edilen ölçümlerle de desteklenmiştir. Prizmatik, yatay bir kanal içine şaşırtmalı olarak yan duvarlara yerleştirilen mahmuzlar arasında (Şekil 6) oluşan 3B akım deneysel olarak incelenmiştir [11]. Buradaki amaç, mahmuzlar arasından hızlanarak geçen akımın oluşturduğu mahmuzlar etrafındaki vorteksler ve hızlanan akımla birlikte düşen su derinliğinin neden olduğu 3B akımın SAD ile ne ölçüde hesaplanabileceğine ışık tutmaktır. Çok sayıda vorteks yapısının neden olduğu karışım ve yüksek türbülans, akımın 3B olma özelliğini öne çıkarmaktadır. Böyle bir durumda SAD çözümünün özellikle hız dağılımları bakımından geçersiz olacağı açık olmakla birlikte, su yüzü profili hesabının geçerli olup olmayacağı tartışılabilir bir durumdur. Nitekim, bazı 3B çözümlerde su yüzü profilinin SAD çözümünden elde edildiği de bilinmektedir. Laboratuvar ortamındaki fiziki modelde farklı debiler ve mansap koşulları 
için su yüzü profilleri ölçülmüş ve SAD çözümleriyle karşılaştırılmıştır. Vorteks yapıları nedeniyle akım oldukça çalkantılı olduğundan, su yüzü ölçümünde minimum ve maksimum seviyeler okunmuş ve ortalama değerler bulunmuştur. Kanal sonunda kontrollü ve kontrolsüz çıkış durumları denenmiştir. Burada deneylerden sadece bir tanesi, kontrolsüz çıkış durumunda alınan ölçümler, sayısal çözüm ile karşılaştırılmıştır. Diğer deneylerde de durum farklı değildir.

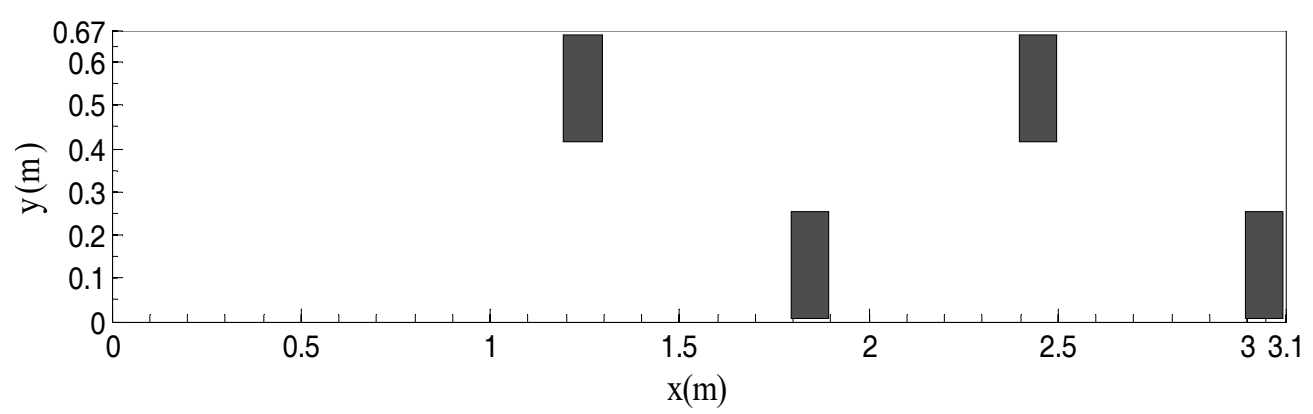

Şekil 6. Prizmatik, yatay kanal içinde yerleştirilen şaşırtmalı mahmuzlar [11]

Sayısal çözümde duvarlarda kaymaz sınır koşulunu sağlamak için Denklem (2) içindeki viskoz terimler dahil edilmiş ve Denklem (4)'te tanımlandığı şekliyle türbülans gerilmeleri de hesaba katılmıştır. Türbülans viskozitesinin derinlik integral değeri tüm akım alanı için sabit tutulmuş ve sayısal deneyler sonucunda $0.007 \mathrm{~m}^{2} / \mathrm{s}$ olarak bulunmuştur. $\mathrm{Bu}$ aşamada hız dağılımları ile ilgili bir karşılaştırma yapılmayacağından türbülans viskozitesinin tüm akım alanında sabit tutulmasında bir sakınca görülmemiştir. Girişte ölçülen su derinliği ve birim debiler sınır şartı olarak uygulanmış, çıkışta ise akım yönünde sıfır türev uygulaması yapılmıştır. Çıkış sınır koşulunun akımı memba yönünde etkilememesi için hesap alanı uzatılarak, çıkış sınır koşulu yeterince uzak bir kesitte uygulanmıştır.

Deney kanalında $0.06 \mathrm{~m}^{3} / \mathrm{s}$ debi için yapılan su yüzü ölçümleri Şekil 7'de sunulmuştur. Giriş bölgesinde mahmuzlar arkasında yükselen su seviyesi ile akım kritik-altı rejimde olup, bloklar arasından geçtikçe hızlanmakta, su derinliği azalmakta ve Froude sayısı artarak kritik-üstü rejime geçmektedir. Doğal olarak bu bölgede SAD derivasyonunda ihmal edilen düşey hız bileşeni önemli olmakta, basınç dağılımı da hidrostatik dağılımdan farklılaşmaktadır. SAD sayısal çözümünden elde edilen su yüzü profili Şekil 8'de sunulmuştur. Genel olarak iyi bir uyum sağlanmakla birlikte, akım yönünde artan mahmuz sayısı geçildikçe hesaplanan su yüzü profili giderek ölçülenden farklılaşmaktadır. Bu gözlemi daha açık görebilmek amacıyla, kanal aksı boyunca orta eksende ölçülen en düşük ve en yüksek su seviyeleri ve hesaplanan su derinlikleri Şekil 9'da karşılaştırılmıştır. Özellikle 3'üncü mahmuzdan sonra hesaplanan su derinliklerinin ölçülen iniş-çıkışı yakalayamadığı görülmektedir. 
Siğ Akım Denklemlerinin Hidrolikte Kullanılması Üzerine Değerlendirmeler

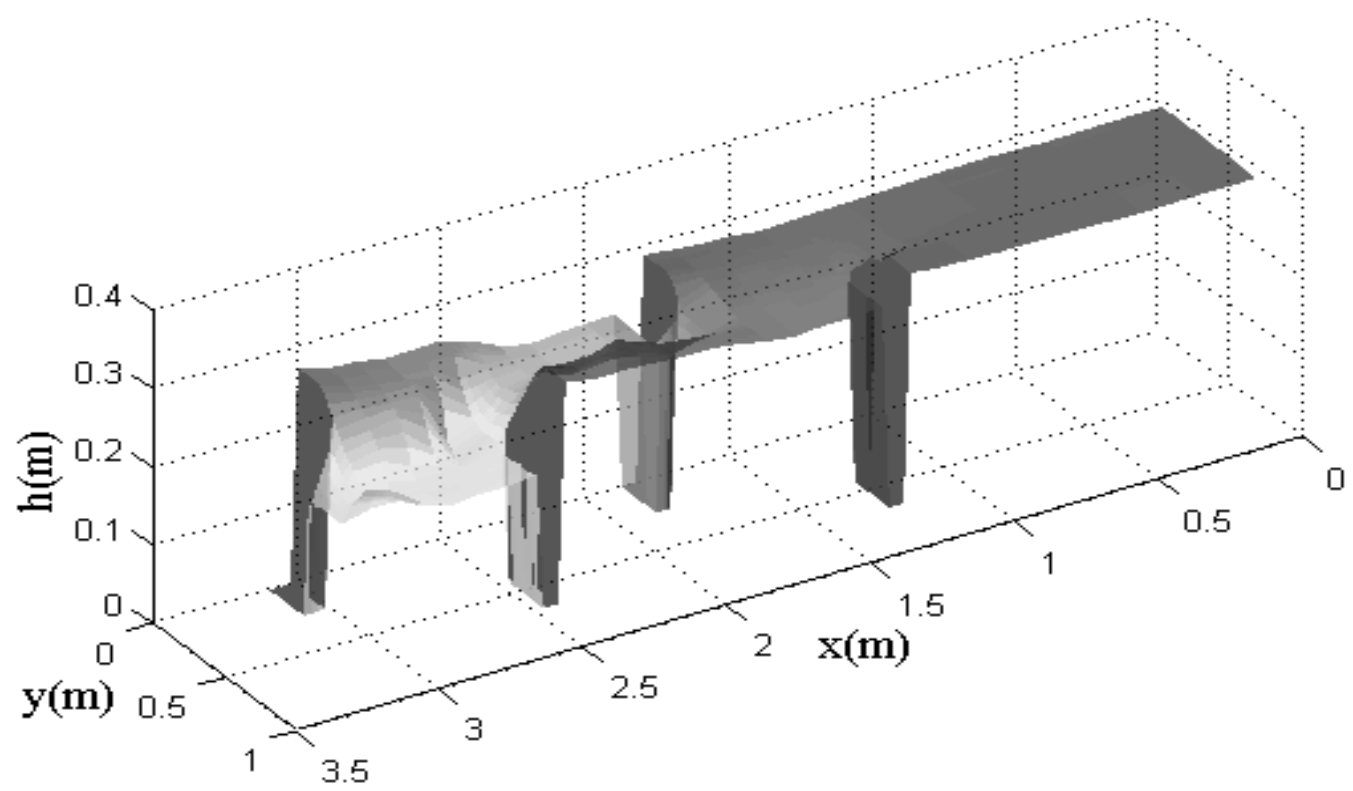

Şekil 7. Yatay kanalda yerleştirilen şaşırtmalı mahmuzlar arasında ölçülen su yüzü profili [11]

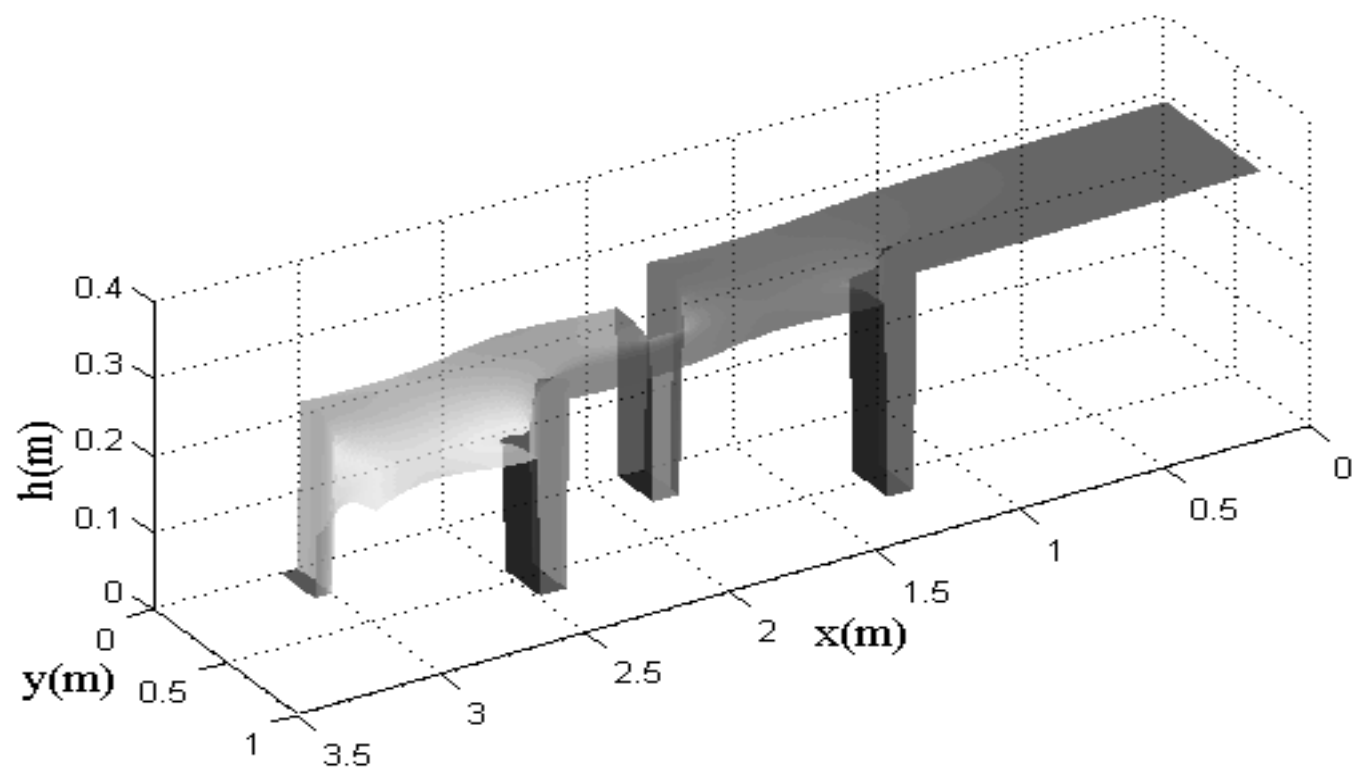

Şekil 8. Yatay kanalda yerleştirilen şaşırtmalı mahmuzlar arasında hesaplanan su yüzü profili 


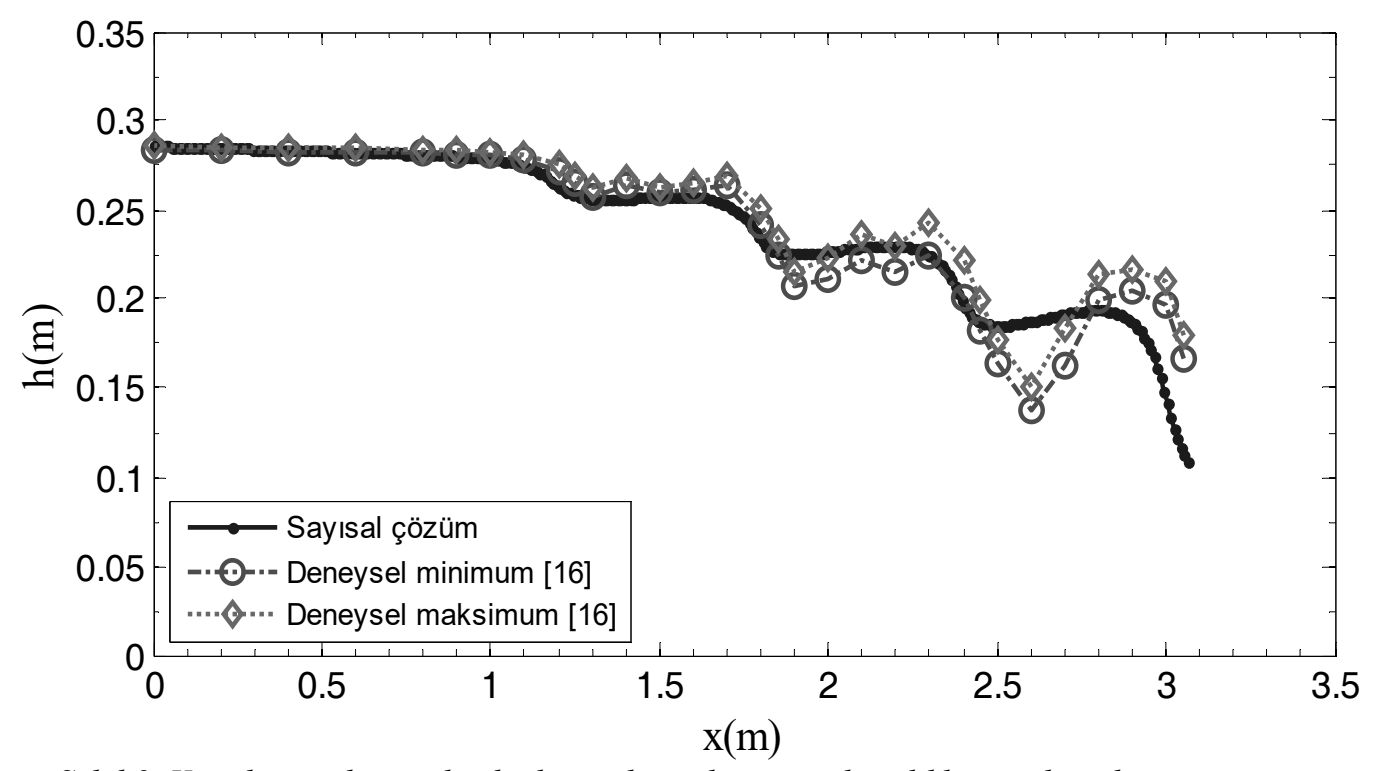

Şekil 9. Kanal orta ekseninde ölçülen ve hesaplanan su derinliklerinin karşılaştırması
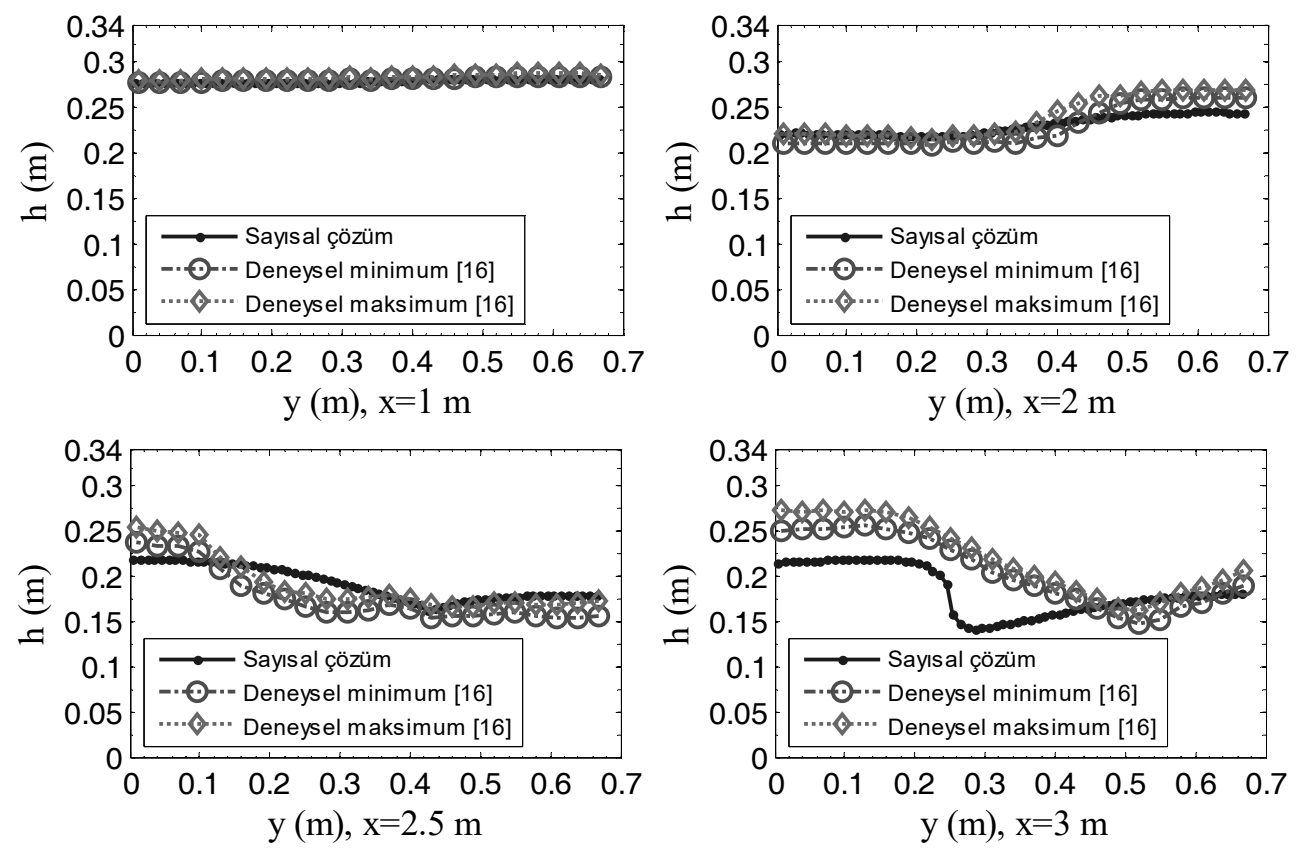

Şekil 10. Girişten çıkışa belirli kesitlerde ölçülen ve hesaplanan su derinliklerinin karşılaştırması 
Siğ Akım Denklemlerinin Hidrolikte Kullanılması Üzerine Değerlendirmeler

$\mathrm{Bu}$ durumu daha iyi gözleyebilmek için belirli en-kesitlerde ölçülen ve hesaplanan su derinlikleri Şekil 10'da gösterilmiştir. Birinci mahmuzdan hemen önce $(x=1 \mathrm{~m})$ hesaplanan ve ölçülen değerler tam olarak örtüşmektedir. İkinci mahmuzdan hemen sonra $(x=2 \mathrm{~m})$ mahmuza ters yönde bir farklılaşma görülmektedir. Üçüncü mahmuz $(x=2.5$ $\mathrm{m})$ sonrasında sapmalar artmakta ve dördüncü mahmuzdan sonra $(x=3 \mathrm{~m})$ hesaplanan su yüzü profili ile ölçümler belirgin şekilde ayrışmaktadır. Süreklilik denkleminin kanal boyunca hacim korunumunu tam olarak sağladığı düşünülürse, mahmuzlar arasında sağasola savrulan akımda düşey ivmelenme artmakta ve SAD çözümü kanal içinde momentum korunumunu sağlayamamaktadır.

Sayısal çözümden elde edilen derinlik ortalamalı hızlardan akım çizgileri elde edilmiş ve sonuç Şekil 11'de sunulmuştur. Yatay düzlemde mahmuzlardan sonra oluşan büyük vorteks yapıların belirgin bir şekilde canlandırıldığı görülmektedir. Ancak, kanal tabanına yakın, düşey düzlemlerde oluşan vortekslerin varlığ 1 ve $\mathrm{SAD}$ çözümünün bunlara duyarsız kalacağı da bilinmektedir.

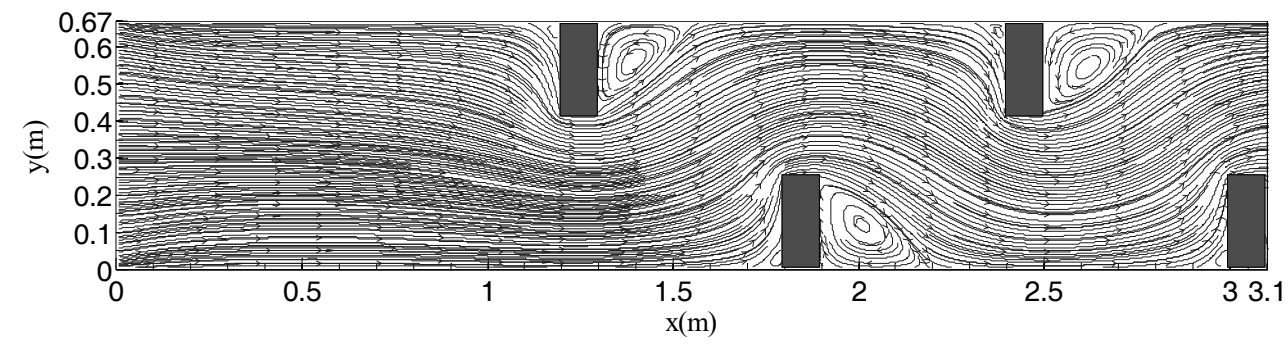

Şekil 11. Derinlik ortalamalı hızlardan elde edilen akım çizgileri

Yukarıdaki gözlemlerden SAD çözümlerinin akım içinde bir adet engelin neden olacağı 3Boyutluluktan çok fazla etkilenmeden oldukça doğru sonuçlar verebileceğini ifade etmek mümkündür. Ancak, 3-Boyutluluğa neden olan engel sayısı arttıkça SAD çözümü ile gerçek akım arasında giderek artan bir ayrışma oluşmakta ve hesaplanan su derinlikleri ile gerçek değer arasındaki fark artmaktadır.

\subsection{Bileşik Kesitli Prizmatik Kanalda Üniform Akım}

Yukarıda anlatılan birinci örnekte viskoz terimler tamamen ihmal edilmişti. İkinci örnekte ise viskoz terimler hesaplamaya tam olarak katılmış fakat türbülans viskozitesi tüm akım alanı için sabit bir değerle ifade edilmişti. Açık kanal akımlarında SAD çözümü ile doğru hız profilleri hesaplamak için türbülans yapısının tam olarak modellenmesi gerekir. $\mathrm{Bu}$ anlamda birçok çalışma yapılmış olmakla birlikte ([12], [13], [14], [15], [16]) SAD çözümleri için henüz genel kabul görmüş bir derinlik integralli türbülans modeli yoktur. Yapılan bazı çalışmalarda ise bir model tanımlamak yerine ampirik ifadelerle deneysel verilere uyum sağlanması denenmiştir [17]. Buradaki zorluk, gerçekte 3-Boyutlu olan türbülansın 2-Boyuta indirgenmesinin vorteks oluşumu gibi temel türbülans dinamikleri ile çelişmesidir. 
Açık kanal akımları, kanal duvarları ve serbest yüzey ile sınırlanmış bir iç-akımdır ve sınır tabaka oluşumları akımın genel karakterini belirler. Akım içindeki bir noktada türbülans, en basit ifade ile, o noktanın akımı sınırlayan tüm duvarlara olan ağırlıklı uzaklığına bağımlıdır. Genel olarak SAD, akımın üçüncü boyutuna, yani derinlik boyunca değişimlere duyarsızdır. Dolayısıyla, SAD çözümünde türbülans modellenecekse ihtiyaç duyulan en öncelikli bilgi, akımı sınırlayan duvarların uzaklığı veya türbülans için bir karışım uzunluğunun (mixing length) tanımlanmasıdır. Bu tanım akımın gerçekleştiği 3B ortamı yeterince doğru temsil edebilmelidir. Bu bağlamda, prizmatik kanallarda üniform akım için daha önce yapılan bir çalışmadan [18] yararlanılacaktır. Bu çalışmada öncelikle akım üniform varsayılmakta ve bu nedenle değişkenlerde akım $(x-)$ yönünde bir değişim söz konusu olmamaktadır. Ancak kesit içinde akımın 3 hız bileşeni de hesaplanmaktadır. Akım üniform olsa da türbülansın yöne duyarlı karakteristiği nedeniyle köşelerde türbülansın beslediği ikincil akımlar oluşmaktadır. Akım yönüne dik bir kesit içinde birbirine ters dönen vorteks yapıları oluşmakta ve ana akım hız dağılımlarını önemli ölçüde etkilemektedir. Bu nedenle bir kesit içinde türbülansın beslediği ikincil akımlar da ilgili momentum denklemlerinin çözümü ile hesaplanmaktadır. Söz konusu çalışmada [18] tanımlanan türbülans modeli kanalın 3-Boyutluluğunu temsil eden bir 'türbülans karışım boyu' tanımlamakta ve ayrıca türbülans gerilmelerini tanımlarken deformasyon ifadeleri ile gerilmeler arasında lineer olmayan bir ilişki kurmaktadır. Böylece, ikincil akımlar ve onların neden olduğu, kesit içinde momentumun yeniden dağılımı doğru olarak hesaplanabilmektedir.

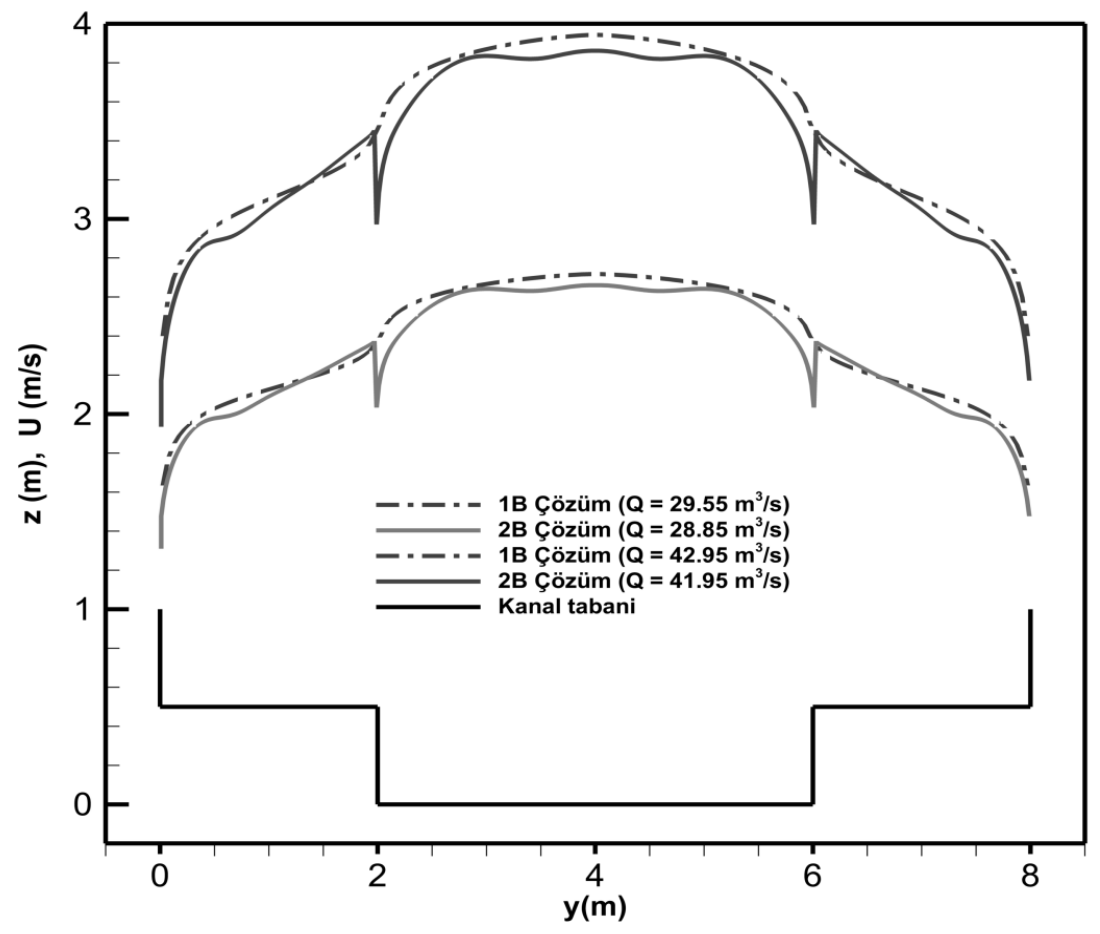

Şekil 12. 1B SAD ve $2 B$ çözümlerden elde edilen derinlik ortalamalı hızların karşılaş̧tırılması 
Siğ Akım Denklemlerinin Hidrolikte Kullanılması Üzerine Değerlendirmeler

$\mathrm{Bu}$ çalışmada kullanılan SAD üniform akım için basitleştirilebilir. Bu durumda $x$-ile değişen tüm terimler atılmış olacaktır. Sadece ana akım yönündeki hızın kanal enine değişimi $u(y)$ hesaplanacaktır. Denklem (4)'te verilen gerilme ifadesinin 1B akım için sadeleşmiş hali

$\tau_{x, y}=\left(v+v_{\mathrm{t}}\right)\left(\frac{\partial u}{\partial y}\right)$

olarak yazılır. Türbülans viskozitesi ise

$v_{\mathrm{t}}=l_{m}^{2}\left(\frac{\partial u}{\partial y}\right)$

olarak tanımlanır. Burada $l_{\mathrm{m}}$ kanal kesiti içinde, önce [18]'de tanımlandığı șekilde hesaplanır ve daha sonra düşey yönde tabandan su yüzüne kadar ortalaması bulunarak elde edilir. Diğer bir ifade ile $l_{\mathrm{m}}$ derinlik integral türbülans karışım uzunluğudur.

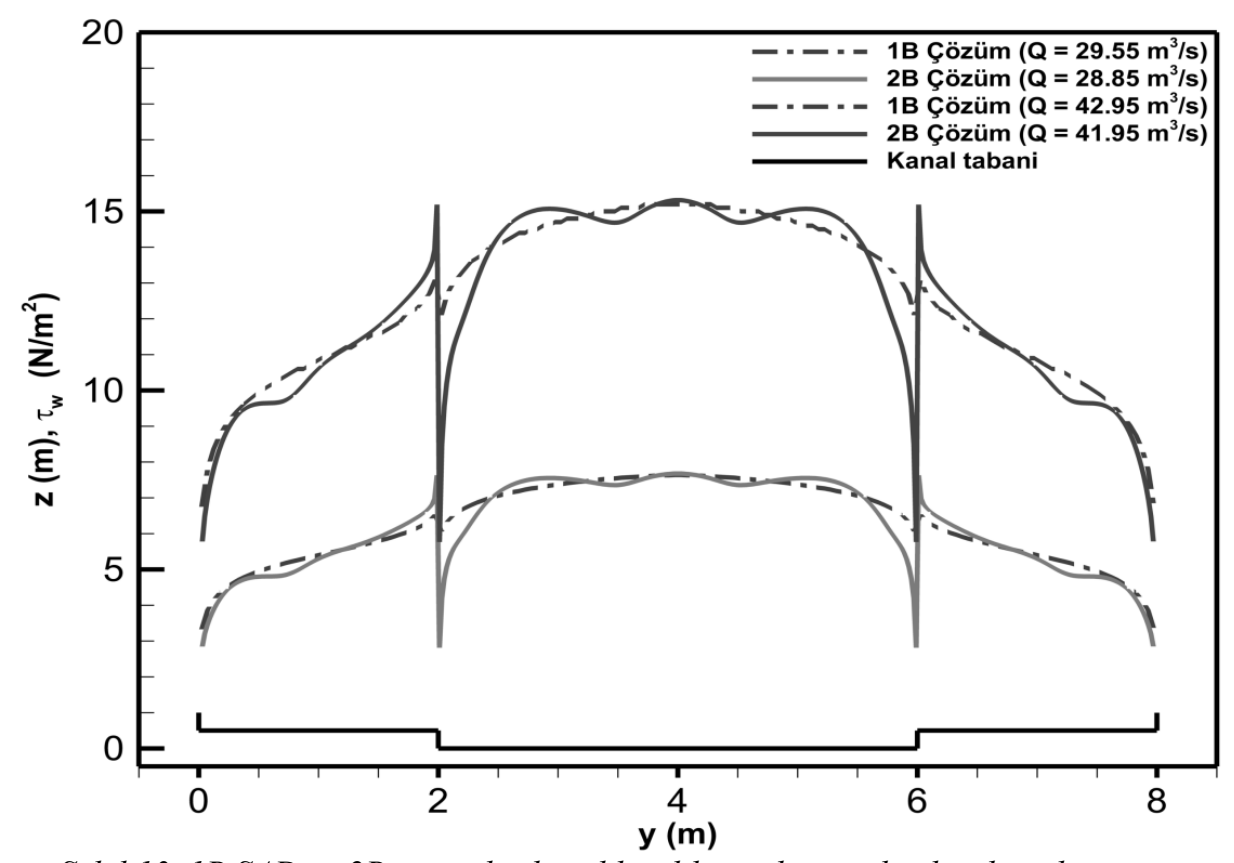

Şekil 13. 1B SAD ve $2 B$ çözümlerden elde edilen cidar gerilmeleri karşılaştırması

Bileşik bir kanalda üniform akım için 1B SAD sonuçları ile 2B sayısal çözüm sonuçları Şekiller 12 ve 13'te sunulmuştur. Burada 2B çözümde herhangi bir sadeleştirme yapılmadan, 3-hız bileșeni için 3-momentum denklemi de çözülmüs ve ikincil akımlar da gerçeğe uygun şekilde temsil edilmiştir. Şekil 12'de iki farklı eğim için hesaplanan derinlik 
ortalamalı hız dağılımları kanal kesiti ile birlikte gösterilmiştir. Sürekli çizgiler 2B çözüm, kesikli noktalı çizgiler 1B SAD çözümdür. Her iki eğim için hesaplanan debi değerleri de şekil üzerinde gösterilmiştir. Bu aşamada hiçbir kalibrasyon yapilmadan sunulan bu karşılaştırmada 1B SAD ile 2B çözümlerin verdiği debiler arasındaki fark \% 2 den azdır. Yeterli miktarda deneysel veri kullanılarak bazı sürtünme parametreleri kalibre edildiği takdirde, bu farkın çok daha düşük değerlere çekilmesi mümkündür.

Aynı akım durumları için hesaplanan cidar gerilmeleri karşılaștırması Şekil 13'te sunulmuştur. 1B çözümün cidar gerilmelerini oldukça başarılı bir doğrulukla hesapladığ gözlenmiştir.

\section{SONUÇLAR}

Bu yazıda SAD için sayısal çözüm yapılarak 3 ayrı akım durumu incelenmiş ve matematik model olarak SAD’nin hangi fiziki koşullar için yeterli/güvenilir sonuçlar vereceği tartışılmıştır. Hiperbolik karakterli olan SAD, akım değişkenlerinde süreksiz çözümlere izin vermektedir. Birinci durum olarak çalışılan kanal içindeki engel etrafından geçen kritik-üstü akım çözümünde sayısal yöntemin bu yöndeki yetenekleri gözlenmiştir. Engel sonrasında oluşan 'duran dalgalar' ve engel yukarısında oluşan hidrolik sıçrama bir süreksizlik örneği olarak hesaplanmıştır.

Fiziksel olarak SAD'nin geçerli olabilmesi için en temel koşul, akım alanının yataydaki boyutunun düsşey boyuttan (derinlikten) yeterince (5 6 kat) büyük olması gerektiğidir. Düssey yöndeki momentum denkleminin kullanılmaması ve düşey ivmenin sıfirlanması sonucu hidrostatik basınç dağılımı da kabul edilmiş olmaktadır. Bu nedenle, akım alanı içindeki bir engel etrafındaki akım SAD ile çalışılırsa, engel yüzeylerindeki basıç̧ların ve dolayısı ile toplam sürükleme kuvvetinin doğru hesaplanamayacağı öngörülebilir. Aslında, SAD çözümlerinden beklenen birincil çıktı su derinliğidir. Su derinliği yeterli bir doğrulukta hesaplanmışsa, derinlik ortalamalı hızlar da doğru olacaktır. Ancak ikinci örnek akımda olduğu gibi tekrarlanan engellerden aşılması durumunda, 3B'luluğun etkileri ile bir noktadan sonra su derinliğinin de hatalı hesaplandığı gözlenmiş̧ir.

Üçüncü örnek durum olarak seçilen bileşik kesitli kanal içindeki üniform akım çözümünde oldukça basit bir türbülans modeli kullanılmıştır. Akım içindeki bir noktanın cidarlardan ağırlıklı uzaklığını hesaplayan bir türbülans karışım uzunluğu oldukça başarılı hız profilleri elde edilmesi için yeterli olmuştur. Bu sonuç, 2B SAD çözümlerinde de tatmin edici türbülans modellerinin geliştirilebileceğine işaret etmektedir.

\section{Kaynaklar}

[1] Toro, E.F., Shock-Capturing Methods for Free-Surface Shallow Flows, Chichester. John Wiley \& Sons, 2001.

[2] Toro, E.F., Riemann Solvers and Numerical Methods for Fluid Dynamics. A Practical Introduction, Berlin, Heidelberg. Springer-Verlag, 2009. 
Sı ̆̆ Akım Denklemlerinin Hidrolikte Kullanılması Üzerine Değerlendirmeler

[3] İsscen, B. N., Computer Code Development for Numerical Solution of Depth Integrated Shallow Water Equations to Study Flood Waves, Yüksek Lisans Tezi, Orta Doğu Teknik Üniversitesi, Ankara, Türkiye, 2015.

[4] Alcrudo, F. and Garcia-Navarro, P., A High-Resolution Godunov Type Scheme in Finite Volumes for the 2D Shallow Water Equations, International Journal for Numerical Methods in Fluids, 16, 489-505, 1993.

[5] Roe, P. L., Approximate Riemann Solvers, Parameter Vectors, and Difference Schemes, Journal of Computational Physics, 43, 357-372, 1981.

[6] Versteeg, H. K., Malalasekera, W., An Introduction to Computational Fluid Dynamics - The Finite Volume Method, Pearson. Prentice Hall, 2007.

[7] Stoker, J. J., Water Waves, the Mathematical Theory with Applications, London. Wiley, 1957.

[8] Wu, C., Huang, G., and Zheng, Y., Theoretical Solution of Dam Break Shock Wave, Journal of Hydraulic Engineering, 125(11), 1210-1215, 1999.

[9] Zoppou, C. and Roberts, S., Explicit Schemes for Dam-Break Simulations, Journal of Hydraulic Engineering, 129(1), 11-34, 2003.

[10] Brufau, P. and Garcia-Navarro, P., Two-Dimensional Dam Break Flow Simulation, International Journal for Numerical Methods in Fluids, 33, 35-57, 2000.

[11] Yilmaz, B., Development and Validation of Two-Dimensional Depth-Averaged Free Surface Flow Solver, Yüksek Lisans Tezi, Orta Doğu Teknik Üniversitesi, Ankara, Türkiye, 2003.

[12] Canelas, R., Murillo, J. and Ferreira, R., Two-Dimensional Depth-Averaged Modelling of ,Dam-Break Flows Over Mobile Beds, Journal of Hydraulic Research, 51(4), 392 407, 2013.

[13] Raisee, M., Jafari, A., Babaei, H. and Iacovides, H., Two-Dimensional Prediction of Time Dependent, Turbulent Flow Around a Square Cylinder Confined in a Channel, International Journal for Numerical Methods in Fluids, 62, 1232-1263, 2010.

[14] Wu, W., Sanchez, A. and Zhang, M., An Implicit 2-D Shallow Water Flow Model on Unstructured Quadtree Rectangular Mesh, Journal of Coastal Research, 59, 15-26, 2011.

[15] Wu, W., Wang, P. and Chiba, N., Comparison of Five Depth-Averaged 2-D Turbulence Models for River Flows, Archives of Hydro-Engineering and Environmental Mechanics, 51(2), 183-200, 2004.

[16] Yu, C. and Duan, J., Two-Dimensional Depth-Averaged Finite Volume Model for Unsteady Turbulent Flow, Journal of Hydraulic Research, 50(6), 599-611, 2012.

[17] Fe, J., Navarrina, F., Puertas, J., Vellando, P. and Ruiz, D., Experimental validation of two depth-averaged turbulence models, International Journal for Numerical Methods in Fluids, 60, 177-202, 2009.

[18] Aydın, İ., Nonlinear Mixing Length Model for Prediction of Secondary Currents in Uniform Channel Flows. Journal of Hydraulic Engineering, 135(2), 146-153, 2009. 